\section{Student Evaluation of the Usefulness of the Self-rating Scale of Self-directed Learning tool in the FdSc in Health and Social Care Course}

\section{Abstract}

Background: Student evaluation is the lifeblood of learning/teaching and the SRSSDL tool is a vehicle to enable students to achieve their goals.

Aim: To evaluate the usefulness of the tool as perceived by the FdSc students.

Methods: A qualitative exploratory approach was used to identify FdSc students' views and experiences of using the SRSSDL tool to establish its effectiveness in developing their SDL skills. A questionnaire comprising of six open-ended semistructured questions was used to collect data.

Analysis: Thematic analysis was used to analyse the data.

Results: The SRSSDL tool was positively evaluated by the students identifying its usefulness in improving their SDL.

Conclusion: Students' evaluation of the SRSSDL tool clearly identified its impact on their learning, developing confidence and their positive experiences when applying the tool.

Keywords: Self-directed learning; Student evaluation; Student motivation; Lifelong learning

\section{Swapna Williamson* and Ramesh Seewoodhary}

\begin{abstract}
Department of Midwifery and Healthcare, College of Nursing, University of West London,
\end{abstract} UK

\section{*Corresponding author: \\ Swapna Williamson \\ Swapna.Williamson@uwl.ac.uk}

Associate Professor, Department of Midwifery and Healthcare, College of Nursing, University of West London, UK.

Tel: 02082094056

Citation: Williamson S, Seewoodhary R (2017) Student Evaluation of the Usefulness of the Self-rating Scale of Self-directed Learning tool in the FdSc in Health and Social Care Course. J Healthc Commun. Vol. 2 No. 4:48

Received: July 11, 2017; Accepted: July 20, 2017; Published: July 29, 2017

\section{Introduction}

Student evaluation is an essential element used by Higher Education Institutions (HEIs). Students benefit when a SelfDirected Learning (SDL) opportunity is appropriately introduced during their course. SDL is a commonly used term in adult education worldwide. It is a process to enable students to take responsibility of their own learning and prioritise what they think is important for them to be independent learners [1]. SDL is an active process which can be enhanced through social interaction within the boundaries of an individual's potential and it occurs continuously throughout a person's lifetime [2]. Ham et al. [3] state that in the context of an ever changing health care environment healthcare professionals need to continually update their knowledge and skills beyond their formal education to meet public expectations. Due to advancements in medical science and technology it is essential that health care professionals become more self-directed in their learning in order to promote their competence and to provide better evidence-based patient care. The learning culture in educational institutions should be learner-centred from the outset to encourage students to manage their learning independently. A range of learning approaches are utilised to facilitate the process of learning. Since the introduction of the Self Directed Learning Readiness Scale (SDLRS) by Guglielmino [4], there was a need to develop a more effective learning tool to encourage students to be more self-aware of their own learning. The Self-Rating Scale of SelfDirected Learning (SRSSDL) developed by Williamson in 2007 is a robust teaching/learning tool (Appendix 1). This provides an opportunity for its users to reflect on their learning progress and behaviour as well as staying motivated [5]. The tool has key elements built in to guide the students to develop further in their careers.

Currently all education institutions collect feedback from their students in different forms to improve the quality of learning they provide. In the past few decades student evaluations of teaching/ learning effectiveness and course evaluations have been given considerable importance in HEls to maintain academic quality, standards and effectiveness of course design and delivery. 
This will benefit students and improve their satisfaction with their higher education experience [6]. Bélanger and Longden [7] argue that teaching academics should be able to assess the appropriateness of the learning outcomes, monitor competence and maintain their level of knowledge and expertise. These could be self-assessed or peer assessed. Students, on the other hand, are better judges of classroom atmosphere, pace of instruction, organisation and use of teaching-learning materials. Feedback and evaluation are the essence of learning for both students and teachers. This strategy helps to improve learning, enhance student satisfaction and helps student retention.

Students on the Foundation Degree Health and Social Care (FdSc) course are required to develop the requisite skills to provide effective healthcare confidently and competently and thus enabling them to progress in their career [8]. These students work as Health Care Assistants (HCAs) and many of them join the university after a 10-25 year gap after completing formal school education. They find the course challenging initially due to having limited academic and study skills. During the course the students are required to use the SRSSDL tool, which enables them to develop a range of learning skills, including learning skills, professional and inter-personal skills. Consequently, they develop confidence and proactively seek information to achieve their learning goals. Knowles [9] explains that adult learners are self-motivated and should take responsibility for their learning. The Royal College of Nursing [10] emphasises that HCAs need to develop their SDL skills which will help them to become independent lifelong learners and safe practitioners.

This paper aims to explore, reflect and critically analyse the FdSc students' evaluation of the SRSSDL tool in developing their SDL. As active users of the tool these students' perceptions are invaluable in determining the usefulness of the tool.

\section{Literature Review}

\section{Self-Directed Learning (SDL) concept}

SDL is an adult learning concept which helps students to initiate their own learning by identifying their learning needs and concerns through supportive and collaborative teacher-student relationships, including peers, rather than only relying on the information received from the teacher. Knowles [11] defines SDL as, "...a process in which individuals take the initiative, with or without the help of others, in diagnosing their learning needs, formulating learning goals, identifying human and material resources for learning, choosing and implementing appropriate learning strategies, and evaluating learning outcomes". SDL is an active process which is more effective in helping students to initiate and take responsibility for their learning rather than traditional learning approaches through continuous monitoring and reflection.

Brockett and Hiemstra [12] view SDL as an instructional process which includes assessing needs, securing learning resources, implementing learning activities, and evaluating learning. This enables learners to take control of their own learning. SDL is the basis of adult learning theory and shifts the focus of learning from the teacher to the learners who are self-motivated, self-reflecting, self-assessing and thus self-directed. Knowles [9] theorises that the andragogical model is based on the assumption that adult learners are generally self-directing learners, which has become a prominent feature of adult education theory and practice. Some educators suggest that adult education is synonymous with SDL [13]. According to Candy [14], SDL is a process and goal directed comprising of four distinct phenomena: personal autonomy, selfmanagement, learner control, and autodidaxy. Williamson [5] points out that SDL enables learners to become goal directed, independent, and inquisitive about their own learning. This enables learners to solve problems more effectively and make decisions in both education and practice environments. PryceMiller [15] maintains that SDL requires a shift in emphasis from teaching to facilitation to be used to assist student learning and a clear strategy is required to introduce SDL into the nursing curriculum. Cadorin et al. [16] report SDL as an essential competence to support a range of healthcare professionals from basic training to continuing education towards the acquisition of life-long learning skills. Self-directed learners are pro-active learners who initiate their own learning rather than be passive learners [11]. Brookfield [17] asserts that SDL enables adults to be responsible for their own learning and also demonstrates the skills for decision making in their learning process.

\section{Self-directed learning in the context of higher education and healthcare}

Progressively SDL has gained popularity over the past few decades and is of increasing interest to HEls in developing students' lifelong learning skills. Guglielmino [4] developed the Self-Directed Learning Readiness Scale (SDLRS) to measure students' readiness for SDL. Whereas, the SRSSDL tool focuses on identifying students' and health care professionals' SDL behaviour and to take appropriate action to improve their learning. Fisher et al. [1] claim that adult learners prefer to take responsibility for meeting their own learning needs by evaluating their learning needs and implementing strategies to achieve their learning goals. Boud [18] points out that higher education and adult education share a common interest in the goal of developing student responsibility and autonomy in learning. SDL skills are associated with lifelong learning, especially in the health and social care setting, where knowledge is continuously changing and advancing. This necessitates healthcare professionals updating their knowledge and skills to ensure patients' safety and the adoption of evidencebased practice.

Brockett and Hiemstra [12] assert that development of learning skills make a learner more self-directed thereby enhancing their ability and willingness to take control of their own learning. SDL involves a series of inter-related learning activities allowing learners to take responsibility for their own learning. It is the basis of adult learning theory and shifts the focus of learning from the teacher to the learner [19]. SDL facilitates learners to become goal directed, autonomous and inquisitive about their own learning, solve problems more effectively and make reasonable decisions in both an educational and a practice environment [5]. Cadorin et al. [20] affirm that there is a growing need to develop 
Self-Directed Learning (SDL) among nurses and other health care workers so that they become better prepared for further university education and for developing lifelong learning skills. As a result they will be able to provide evidence-based care by maintaining knowledge and competence. Shen et al. [21] report that SDL is of great importance to the professional development of nursing students. This enables them to expand the knowledge and skills further and to gain confidence when working in practice.

\section{Self-rating scale of self-directed learning (SRSSDL)}

The focus of the SRSSDL tool is to help students to self-assess and monitor their learning skills. This will assist them to identify their strengths and weaknesses to take appropriate action to improve their learning. This tool has been widely used by academics worldwide to facilitate learning. Williamson [5] illustrates that the tool comprises of sixty learning behaviour statements under five broad categories: (1) Awareness: 12 items relating to learners' awareness of the factors concerning becoming selfdirected learners. (2) Learning strategies: 12 items identifying the various strategies learners should adopt in order to develop SDL skills. (3) Learning activities: 12 items specifying the learning activities learners should actively engage in to help become selfdirected learners. (4) Evaluation: 12 items revealing learners' specific attributes that help them monitor their own learning progress. (5) Interpersonal skills: 12 items relating to learners' skills in interpersonal relationships.

Students' responses for each item are rated by using a five point rating scale: 5-always, 4-often, 3-sometimes, 2-seldom, 1-never. Thus, the maximum and the minimum scores on the SRSSDL are 300 and 60 . This continuum was further divided into three levels: students' SRSSDL scores between 60 to 140, 141 to 220 and 221 to 300 as low, moderate and high level of self-directed learning skills respectively. The coefficient alpha in all five broad categories indicates sufficient correlations which are $0.79,0.73$, $0.71,0.71$, and 0.71 respectively. Williamson [5] also elucidates that the usefulness of students' responses to the SRSSDL items is two-fold: (1) Students self-assess their learning needs, develop an insight into the concept of SDL and plan strategies to improve their learning skills; (2) Teachers identify the students' areas of learning needs, guide them in adopting appropriate strategies in developing their learning skills.

Cadorin et al. [16] state that the SRSSDL tool is useful for assessing SDL skills of a range of healthcare professionals so as to help them to adopt strategies to maintain their professional competence. A range of research study findings revealed that the SRSSDL is an effective tool for self-assessment of SDL for healthcare professionals such as, nursing students, nurses, and radiologist technicians [20,22-24].

Since SRSSDL was developed in 2007, an Italian version 'SRSSDL_ Ita' was validated to contextualise the tool to assess and evaluate the SDL skills of the students and healthcare professionals in Italy. According to Cadorin et al. [25], 'SRSSDL_Ita' was found to be useful to identify SDL abilities of students to achieve their expected learning goals and to become lifelong learners. Cadorin et al. [26] further endorse that 'SRSSDL_Ita' is a valid and practical tool contributing to determine learning needs of students and other healthcare professionals so as to identify and implement strategies to enhance their SDL skills.

From the above review it is evident that development of SDL skills is important as it provides a platform for assessing, evaluating and enhancing skills. These skills are transferable which helps students to take responsibility for their own learning and improve their practice where relevant. The SRSSDL tool has been used to identify students' SDL skills. This study aims to evaluate the benefits of this tool as perceived by FdSc students. The two research questions were: (1) How beneficial is the SRSSDL in enhancing students' SDL? (2) Does the SRSSDL tool impact on student learning?

\section{Research Design and Methods}

This study explores the FdSc students' views, opinions and experiences of using the SRSSDL tool. Parahoo [27] states that qualitative approaches value views of respondents and seek to understand the world in which they live in. A descriptive exploratory qualitative design has been used in this study. This approach is appropriate to collect rich narrative data from a small sample population and analyse the data using broad thematic content analysis methods [28]. The exploratory research focuses on the discovery of experiences, ideas and thoughts which provide opportunities for further insight into these experiences [29].

\section{Setting}

The participants for the study were recruited from a London Higher Education Institution which is currently offering the FdSc in Health and Social Care course.

\section{Sample}

A purposive method of sampling was used as the researchers deliberately selected the participants on the basis of who can provide the necessary data [27]. A total of twenty-five final year FdSc students were recruited for this study. The age ranged from 30 to 50 years and the average age was 40 years. All participants used the SRSSDL tool throughout the course to self-assess and monitor their own learning progress.

\section{Ethical consideration}

This study did not require ethical approval as its primary aim is to help students to learn by using the SRSSDL tool and to assist in lifelong learning. This tool helps students to learn how to learn and improve. Learning in this context should be viewed as an ongoing process. As this process does not involve any risk nor require personal data to be collected ethical approval was not needed [30]. However, the Lead of the School Research Ethics Committee was informed by the author and agreed for the study to proceed. The participants were informed about the purpose of this study by the author during a classroom teaching session at the beginning of the course. All students agreed to participate and consented. The participants were informed and made aware of the implications of the study so that they could decide whether they want more information before they participate or decide not to participate at all [27]. 


\section{Data collection}

On the final day of the FdSc course all participants were provided a set of six questions and were requested to respond to them in writing.

The researchers developed a set of semi-structured open-ended questions as shown below:

1. How did the tool help you to learn?

2. How did the tool contribute in developing your confidence to become an Independent learner?

3. How did the tool facilitate you in the process of interactive and shared learning?

4. Explain how the tool has helped you to become more reflective in your learning?

5. How would the tool be useful for your future learning?

6. Explain the tutor's role in enhancing your learning when using this tool?

All twenty-five participants completed the questions in the classroom and submitted the form to the course leader.

\section{Results and Data Analysis}

Participants' individual responses were coded and grouped into sub-themes, which were later categorised into major themes by the research team.

Students' responses to the 6-item open-ended questionnaire were analysed by the research team and four themes emerged:

1. Self-awareness of learning.

2. Self-confidence and independent learning.

3. Reflective and life-long learning.

4. Group and shared learning.

The themes derived from the participants' evaluation of the SRSSDL tool denotes their understanding of the concept of the SDL behaviour identified in the tool and the impact of the tool in their learning during the course. The response of the participants also identifies the details of what is expected of them as adult learners that helps them to direct and manage their own learning. According to Knowles [31] adult learning should focus beyond the transmission of knowledge and it should also create a psychological climate favourable to learning.

\section{Discussion}

The four themes that emerge from the participant responses to the six open ended questions are all demonstrating key areas of students' learning and skills development from the use of the SRSSDL tool. Each theme is discussed below.

\section{Self-awareness and SDL learning}

SDL is a process in which students take initiative and responsibility for their own learning. According to Candy [14], SDL helps students in developing skills and competencies for them to pursue learning throughout their life span by identifying their strengths and areas for further development to achieve their learning goals. A well-motivated student is likely to do well in any learning situation and with the development of requisite learning skills one is more likely to become a life-long learner. Hiemstra [32] and Brookfield [33] affirm that SDL learners take responsibility to plan, implement and evaluate their own learning and to work independently or with others in order to achieve pre-set learning goals. The participants responding to the items of the SRSSDL tool became aware of the use and importance of SDL and sought support to plan learning activities in order to meet learning goals. SDL skills are essential in order to keep abreast with the current professional knowledge and competence to enhance evidencebased practice. This eventually motivates students to learn and to take responsibility in decision making. Thus, it is paramount that students should take active control of their own learning.

The participants' awareness of the concept of SDL is indicated below:

Participant number 1 stated,

"The SRSSDL tool helps me to identify my learning needs, to set SMART learning goals and develop a realistic action plan".

Some participants said,

"I used the term 'Self-directed learning' before but I did not know what it involved. But the use of the SRSSDL tool helped me to understand the nature of SDL, how to identify my learning needs and how to manage my time effectively achieving my learning goals".

\section{Self-confidence and independent learning}

The participants valued constructive and comprehensive feedback which helped them to improve their learning and enhance their self-confidence. Lunyk-Child et al. [34] state that students undergo a range of experiences, which may begin with negative feelings ending with confidence and development of a range of learning skills including literature searching, reading, writing and communicating effectively. During this process the teacher's timely feedback is important in guiding students' learning. Participant number 5 pointed out:

"I am now able to explore and access relevant sources of information and use evidence based information to improve my practice".

Participant number 3 said,

"Now I can self-monitor my learning progress. I will check my own learning progress with the help of SRSSDL tool and plan activities to improve my skills".

\section{Reflective and life-long learning}

Helping students to take responsibility for their own learning is to empower them in making appropriate choices and taking control of their own learning, self-assessment and reflection. Kaufman [35] states that encouraging students to raise relevant questions 
enables those to develop a deeper understanding of what they already know identify gaps in their knowledge and be able to reflect critically on the learning process and outcomes. Students responding to the SRSSDL items self-reflect and rate themselves in each of the learning behaviours.

Participant number 10 commented,

"Following the use of the SRSSDL tool I will continue to reflect on my learning to improve my knowledge and clinical skills to maintain a good standard in practice".

Davis et al. [36] assert that self-reflection is a component for professional development linked to lifelong learning.

Participant number 6 said,

"My self-directed learning plan is going on well using the SRSSDL tool; I am honest in responding to its items to plan a future learning plan otherwise I will be cheating myself ".

This identifies the participants' ability to reflect and to direct their own learning in order to mitigate gaps in their knowledge. As reflective practitioners the participants are more critical about their learning experiences, identifying gaps in their knowledge and competencies, exploring and using relevant information and resources to improve their practice [36]

Participant number 12 said,

"It helped me to be self-aware of my learning skills and plan for future learning".

Participant number 7 stated,

"SDL activities kept me focused and helped me to embrace the ethos of life-long learning to allow me to evolve in line with the needs of the modern healthcare service."

\section{Group and shared learning}

Positive interaction between the teacher and students enhances students' interpersonal skills, communication, time management and their ability to complete learning tasks. Boud [37] states that students learn meaningfully by explaining their ideas to others and by participating in learning activities with their peers. A combination of various approaches in teaching and learning is beneficial to enhance student learning and experiences. All the participants positively evaluated the teaching/learning strategies used. They expressed:

"I like the small group interactive learning approach; it gives me opportunity to share learning from each other as a team."

A combination of face-to-face and online learning enhances student interactivity and increases the meaningful intellectual exchange between students. Williamson [5] states that selfdirection is the basis of all learning and the effectiveness of learning is relative to an individual's motivation.

Each learner is capable of learning through the effective use of SDL skills but the degree of development varies due to individual differences and the context where students interact; this does not mean that the student must make all decisions or learn alone, nor does it mean that the students do not require teacher support. The role of teacher is to collaborate with their students by facilitating and developing students' full potential in order for them to become effective self-directed learners through building and maintaining a harmonious team relationship. Collaborative control facilitates motivation, responsibility and self-direction in learners. For example, searching, exploring and managing information is the responsibility of the students but they need challenges, support and feedback to develop information literacy. The role of the teacher and librarian is very important in order for the students to become self-directed learners. Kell and Van Deursen [38] affirm the responsibility of educators to help students acquire SDL skills, which can be applied to practice. In order to promote student learning the traditional teachers' role is still valued and is important for imparting information. They take on a 'facilitator' role thus motivating students to learn. The role of the teacher is to create an environment in which students engage actively in their learning.

Participant number 20 said,

"Initially I had the problem of understanding the meaning of selfdirected learning but with the teacher's guidance I have become an independent learner. I will be able to use my learning skills for coaching and mentoring others."

Participant number 18 said,

"For me to remain focused on my learning process teachers' guidance is essential to clarify my doubts regarding goal setting, learning strategies and how to develop reflection skills".

Vygotsky [2] views that social interaction plays a fundamental role in the process of cognitive development. He goes on stating that knowledge is constructed through interaction with others; this is based on the theory that promotes learning contexts in which students act, interact and share learning experiences through collaboration with peers and developing students' ability to solve problems independently. Thus, students' active role in learning through continuous social interaction helps in their cognitive development, independence, resilience and motivation for further learning.

The SRSSDL tool is a valuable tool for facilitating and developing students' learning, in particular transferable skills which can be used in various settings, for example in healthcare and teaching/ learning environments. Student feedback and evaluation are important to identify students' progress regarding their learning experiences and to establish what is working well and what aspects may need improving [39]. It illuminates the quality of teaching/learning and assessment strategies which enhance students' learning and also identify appropriate measures to meet the students' learning needs.

\section{Conclusion}

The students' evaluation of the SRSSDL tool clearly demonstrates how this has impacted on their learning in the classroom and also in giving them more confidence to work in their respective practice areas. It has made a positive difference in their learning 
behaviour. The evaluation demonstrates the usefulness of the tool in the teaching and learning process. The students have benefitted by reflecting on the importance of transferable skills to help them to adapt in different practice areas.. Development of SDL skills is essential for healthcare practitioners to maintain their professional skills and competencies in order to meet the challenges presented in the ever changing health care system. Students receiving appropriate instructional and motivational support are able to take on the responsibility of their own learning through reflection on how they learn and develop their skills in order to achieve their goals. This enables them to change from passive recipients of information to active controllers of their learning. The teacher acts as a facilitator, thus empowering students by encouraging active involvement in their learning.

\section{References}

1 Fisher M, King J, Tague G (2001) Development of a self-directed learning readiness scale for nursing education. Nurse Educ Today 21: 516-525.

2 Vygotsky LS (1978) Mind in society: The development of higher psychological processes. Cambridge: Harvard University Press.

3 https://www.kingsfund.org.uk/publications/transforming-deliveryhealth-and-social-care

4 Guglielmino LM (1977) Development of the self-directed learning readiness scale unpublished doctoral dissertation, University of Georgia. Dissertation Abstracts International 38: 6467.

5 Williamson SN (2007) The development of self-rating scale of selfdirected learning. Nurse Res 14: 65-72.

6 https://www.heacademy.ac.uk/system/files/id352_collecting_and_ using_student feedback_a guide to good_practice.pdf

7 Bélanger CH, Longden B (2010) The effective teacher's characteristics as perceived by students. Tertiary Education and Management 15 323-340.

8 Griffin R, Arbuthnot R (2012) Better care through better training: evaluation of an HCA development programme. BJHCA 6: 35-38.

9 http://www.umsl.edu/ henschkej/articles/a_The_\%20Modern_ Practice_of_Adult_Education.pdf

10 https://www.rcn.org.uk/professional-development/publications/ pub-004214

11 Knowles MS (1975) Self-directed learning: a guide for learners and Teachers. New York: Cambridge Book Co, p: 135.

12 http://roghiemstra.com/sdlindex.html

13 Wilcox S (1996) Fostering self-directed learning in university setting. Studies in Higher Education 21: 165-176.

14 http://trove.nla.gov.au/work/6448891

15 Pryce-Miller M (2010) Are first year undergraduate students prepared for self-directed learning. Nurs Times 106: 21-23.

16 Cadorin L, Suter N, Saiani S, Williamson SN, Palese A (2011) SelfRating Scale of Self-Directed Learning (SRSSDL): Preliminary results from the Italian validation process. J Res Nurs 16: 363-373.

17 Brookfield SD (1993) Self-directed learning, political clarity, and the critical practice of adult education. Adult Educ Q 43: 227-242.
This will guide them to further develop learning skills and helps students to take more responsibility in their life-long learning. The findings of this study also demonstrate that there is improvement in the FdSc students' SDL skills.

The authors feel that there is scope for conducting further research in this area to establish the association between the use of the SRSSDL tool and students' academic performance by using a larger sample size with other courses. A follow-up study of the professional and personal development of these students two years after their graduation would be helpful to monitor and evaluate their progress further. Having considered the need for development of SDL skills in HEI students there is potential for the SRSSDL to be introduced into the curricula in order to develop students' SDL skills and help promote life-long learning.

18 http://www.apa.org/education/k12/learners.aspx

19 Hartzell J (2007) Adult learning theory in medical education. Am J Med 120: e11.

20 Cadorin L, Bortoluzzi G, Palese A (2013) The Self-Rating Scale of SelfDirected Learning (SRSSDL): a factor analysis. Nurse Educ Today 33 : 1511-1516.

21 Shen WQ, Chen HL, Hu Y (2014) The validity and reliability of the self-directed learning instrument (SDLI) in mainland Chinese nursing students. BMC Med Educ 14: 108

22 Adelaida Z (2010) Self-Rating Scale of Self-Directed Learning (SRSSDL): preliminary results from the Italian validation process. J Res Nurs 16: 375-376.

23 Shen WQ, Yan H (2011) The reliability and validity of self-rating scale for self-directedness in learning (in Chinese). Chinese Nurs Res 46: 1211-1213

24 Cadorin L, Suter N, Dante A, Williamson SN, Devetti A, et al. (2013) Self-directed learning competence assessment within different healthcare professionals and amongst students in Italy. J Nurs Educ Pract 12: 153-158

25 Cadorin L, Cheng S, Palese A (2016) Concurrent validity of self-rating scale of self-directed learning and self-directed learning instrument among Italian nursing students. BMC Nurs 15: 20.

26 Cadorin L, Ghezzi V, Camillo M, Palese A (2017) The self-rating scale of self-directed learning tool: findings from a confirmatory factor analysis. J Nurs Educ Pract 7: 31-37.

27 https://he.palgrave.com/page/detail/NursingResearch/?K=9781137281265

28 Schneider Z, Whitehead D, LoBiondo-Wood G, Haber J (2013) Nursing and midwifery research-methods and appraisal for evidence-based practice ( $3^{\text {rd }}$ edn.). Sydney: Elsevier, p: 488.

29 Polit DF, Beck CT (2014) Essentials of nursing research: methods, appraisals, and utilization. Milano: McGraw Hill, p: 554.

30 https://www.gov.uk/government/uploads/system/uploads/ attachment_data/file/213753/dh_133993.pdf

31 http://academic.regis.edu/ed205/knowles.pdf

32 http://ccnmtl.columbia.edu/projects/pl3p/Self-Directed\%20 Learning.pdf 
33 http://as.wiley.com/WileyCDA/WileyTitle/productCd1555423558,subjectCd-ED23.html

34 Lunyk-Child OI, Crooks D, Ellis PJ, Ofosu C, O'Mara L, et al. (2001) Self-directed learning: faculty and student preparations. J Nurs Educ 40: 116-123.

35 Kaufman DM (2003) ABC of learning and teaching in medicine: applying educational theory in practice. BMJ 326: 213-216.

36 Davis DA, Mazmanian PE, Fordis M, Van Harrison R, Thorpe KE, et al. (2006) Accuracy of physician self-assessment compared with observed measures of competence. JAMA 296: 1094-1102.
37 Boud D (2001) Introduction-making the move to Peer Learning. In: Boud D, Cohen R and Simpson J (eds.) peer learning in higher education: learning from and with each other. London: Kogan Page Ltd., p: 196.

38 Kell C, Van Deursen R (2002) Student learning preferences reflect curricula change. Med Teach 24: 32-40.

39 Stuart CC (2013) Assessment, supervision and support in clinical practice: a guide for nurses, midwives and other health professionals. London: Churchill Livingstone, p: 357. 


\section{Appendix 1}

ID

Date-

\section{Self-Rating Scale for Self-Directed Learning (SRSSDL) Tool}

The aim of this tool is to identify learner's levels of self-directedness in learning in higher education. Please read and encircle the most appropriate response to each statement indicating the level at which you rate yourself. Please note that your first reaction to the statement is the most accurate response; therefore do not spend too long a time on each item.

The 'any other' space is provided for you to add any other issues about self-directedness in learning you think relevant. A 'scoring sheet' is included for you to assess the level of your self-directedness in learning.

Response Key: 5 = Always 4 = Often $\quad 3$ = Sometimes $\quad 2=$ Seldom $\quad 1=$ Never

\begin{tabular}{|c|c|c|c|c|c|c|}
\hline 1 & Awareness & \multicolumn{5}{|c|}{ Score } \\
\hline 1.1 & Identify my own learning needs & 5 & 4 & 3 & 2 & 1 \\
\hline 1.2 & $\begin{array}{l}\text { I am able to select the best method for my own } \\
\text { learning }\end{array}$ & 5 & 4 & 3 & 2 & 1 \\
\hline 1.3 & $\begin{array}{l}\text { I consider teachers as facilitators of learning } \\
\text { rather than providing information only }\end{array}$ & 5 & 4 & 3 & 2 & 1 \\
\hline 1.4 & $\begin{array}{l}\text { I keep up to date on different learning } \\
\text { resources available }\end{array}$ & 5 & 4 & 3 & 2 & 1 \\
\hline 1.5 & I am responsible for my own learning & 5 & 4 & 3 & 2 & 1 \\
\hline 1.6 & $\begin{array}{l}\text { I am responsible for identifying my areas of } \\
\text { deficit }\end{array}$ & 5 & 4 & 3 & 2 & 1 \\
\hline 1.7 & I am able to maintain self-motivation & 5 & 4 & 3 & 2 & 1 \\
\hline 1.8 & I am able to plan and set my learning goals & 5 & 4 & 3 & 2 & 1 \\
\hline 1.9 & I have a break during long periods of work & 5 & 4 & 3 & 2 & 1 \\
\hline 1.10 & $\begin{array}{l}\text { I need to keep my learning routine separate } \\
\text { from my other commitments }\end{array}$ & 5 & 4 & 3 & 2 & 1 \\
\hline 1.11 & I relate my experience with new information & 5 & 4 & 3 & 2 & 1 \\
\hline 1.12 & $\begin{array}{l}\text { I feel that I am learning despite not being } \\
\text { instructed by a lecturer }\end{array}$ & 5 & 4 & 3 & 2 & 1 \\
\hline
\end{tabular}




\begin{tabular}{|c|c|c|c|c|c|c|}
\hline 1.13 & 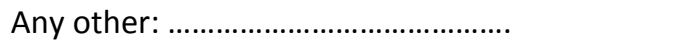 & 5 & 4 & 3 & 2 & 1 \\
\hline 2 & Learning Strategies & \multicolumn{5}{|c|}{ Score } \\
\hline 2.1 & I participate in group discussions & 5 & 4 & 3 & 2 & 1 \\
\hline 2.2 & I find peer coaching effective & 5 & 4 & 3 & 2 & 1 \\
\hline 2.3 & $\begin{array}{l}\text { I find 'role play' is a useful method for complex } \\
\text { learning }\end{array}$ & 5 & 4 & 3 & 2 & 1 \\
\hline 2.4 & $\begin{array}{l}\text { I find inter-active teaching-learning sessions } \\
\text { more effective than just listening to lectures }\end{array}$ & 5 & 4 & 3 & 2 & 1 \\
\hline 2.5 & I find simulation in teaching-learning useful & 5 & 4 & 3 & 2 & 1 \\
\hline 2.6 & I find learning from case studies useful & 5 & 4 & 3 & 2 & 1 \\
\hline 2.7 & $\begin{array}{l}\text { My inner drive directs me towards further } \\
\text { development and improvement in my learning }\end{array}$ & 5 & 4 & 3 & 2 & 1 \\
\hline 2.8 & I regard problems as challenges & 5 & 4 & 3 & 2 & 1 \\
\hline 2.9 & $\begin{array}{l}\text { I arrange my self-learning routine in such a way } \\
\text { that it helps develop a permanent learning } \\
\text { culture in my life }\end{array}$ & 5 & 4 & 3 & 2 & 1 \\
\hline 2.10 & $\begin{array}{l}\text { I find concept mapping is an effective method } \\
\text { of learning }\end{array}$ & 5 & 4 & 3 & 2 & 1 \\
\hline 2.11 & $\begin{array}{l}\text { I find modern educational interactive } \\
\text { technology enhances my learning process }\end{array}$ & 5 & 4 & 3 & 2 & 1 \\
\hline 2.12 & I am able to decide my own learning strategy & 5 & 4 & 3 & 2 & 1 \\
\hline 2.13 & 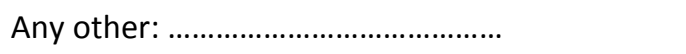 & 5 & 4 & 3 & 2 & 1 \\
\hline 3 & Learning Activities & \multicolumn{5}{|c|}{ Score } \\
\hline 3.1 & I rehearse and revise new lessons & 5 & 4 & 3 & 2 & 1 \\
\hline 3.2 & $\begin{array}{l}\text { I identify the important points when reading a } \\
\text { chapter or an article }\end{array}$ & 5 & 4 & 3 & 2 & 1 \\
\hline 3.3 & $\begin{array}{l}\text { I use concept mapping/outlining as a useful } \\
\text { method of comprehending a wide range of } \\
\text { information }\end{array}$ & 5 & 4 & 3 & 2 & 1 \\
\hline 3.4 & $\begin{array}{l}\text { I am able to use information technology } \\
\text { effectively }\end{array}$ & 5 & 4 & 3 & 2 & 1 \\
\hline 3.5 & $\begin{array}{l}\text { My concentration intensifies and I become } \\
\text { more attentive when I read a complex study } \\
\text { content }\end{array}$ & 5 & 4 & 3 & 2 & 1 \\
\hline
\end{tabular}




\begin{tabular}{|c|c|c|c|c|c|c|}
\hline 3.6 & $\begin{array}{l}\text { I keep annotated notes or a summary of all my } \\
\text { ideas, reflections and new learning }\end{array}$ & 5 & 4 & 3 & 2 & 1 \\
\hline 3.7 & $\begin{array}{l}\text { I enjoy exploring information beyond the } \\
\text { prescribed course objectives }\end{array}$ & 5 & 4 & 3 & 2 & 1 \\
\hline 3.8 & I am able to relate knowledge with practice & 5 & 4 & 3 & 2 & 1 \\
\hline 3.9 & $\begin{array}{l}\text { I raise relevant question(s) in teaching-learning } \\
\text { sessions }\end{array}$ & 5 & 4 & 3 & 2 & 1 \\
\hline 3.10 & $\begin{array}{l}\text { I am able to analyse and critically reflect on } \\
\text { new ideas, information or any learning } \\
\text { experiences }\end{array}$ & 5 & 4 & 3 & 2 & 1 \\
\hline 3.11 & I keep an open mind to others' point of view & 5 & 4 & 3 & 2 & 1 \\
\hline 3.12 & $\begin{array}{l}\text { I prefer to take any break in between any } \\
\text { learning task }\end{array}$ & 5 & 4 & 3 & 2 & 1 \\
\hline 3.13 & 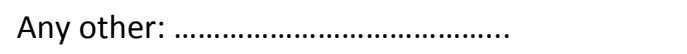 & 5 & 4 & 3 & 2 & 1 \\
\hline 4 & Evaluation & \multicolumn{5}{|c|}{ Score } \\
\hline 4.1 & $\begin{array}{l}\text { I self-assess before I get feedback from } \\
\text { instructors }\end{array}$ & 5 & 4 & 3 & 2 & 1 \\
\hline 4.2 & $\begin{array}{l}\text { I identify the areas for further development in } \\
\text { whatever I have accomplished }\end{array}$ & 5 & 4 & 3 & 2 & 1 \\
\hline 4.3 & I am able to monitor my learning progress & 5 & 4 & 3 & 2 & 1 \\
\hline 4.4 & $\begin{array}{l}\text { I am able to identify my areas of strength and } \\
\text { weakness }\end{array}$ & 5 & 4 & 3 & 2 & 1 \\
\hline 4.5 & $\begin{array}{l}\text { I appreciate when my work can be peer } \\
\text { reviewed }\end{array}$ & 5 & 4 & 3 & 2 & 1 \\
\hline 4.6 & $\begin{array}{l}\text { I find both success and failure inspire me to } \\
\text { further learning }\end{array}$ & 5 & 4 & 3 & 2 & 1 \\
\hline 4.7 & $\begin{array}{l}\text { I value criticism as the basis of bringing } \\
\text { improvement to my learning }\end{array}$ & 5 & 4 & 3 & 2 & 1 \\
\hline 4.8 & $\begin{array}{l}\text { I monitor whether I have accomplished my } \\
\text { learning goals }\end{array}$ & 5 & 4 & 3 & 2 & 1 \\
\hline 4.9 & I check my portfolio to review my progress & 5 & 4 & 3 & 2 & 1 \\
\hline 410 & I review and reflect on my learning activities & 5 & 4 & 3 & 2 & 1 \\
\hline 4.11 & I find new learning challenging & 5 & 4 & 3 & 2 & 1 \\
\hline 4.12 & I am inspired by others' success & 5 & 4 & 3 & 2 & 1 \\
\hline
\end{tabular}




\begin{tabular}{|c|c|c|c|c|c|c|}
\hline 4.13 & Any other: & 5 & 4 & 3 & 2 & 1 \\
\hline 5 & Interpersonal Skills & \multicolumn{5}{|c|}{ Score } \\
\hline 5.1 & $\begin{array}{l}\text { I intend to learn more about other cultures and } \\
\text { languages I am frequently exposed to }\end{array}$ & 5 & 4 & 3 & 2 & 1 \\
\hline 5.2 & I am able to identify my role within a group & 5 & 4 & 3 & 2 & 1 \\
\hline 5.3 & $\begin{array}{l}\text { My interaction with others helps me to develop } \\
\text { the insight to plan for further learning }\end{array}$ & 5 & 4 & 3 & 2 & 1 \\
\hline 5.4 & I make use of any opportunities I come across & 5 & 4 & 3 & 2 & 1 \\
\hline 5.5 & I need to share information with others & 5 & 4 & 3 & 2 & 1 \\
\hline 5.6 & $\begin{array}{l}\text { I maintain good inter-personal relationships } \\
\text { with others }\end{array}$ & 5 & 4 & 3 & 2 & 1 \\
\hline 5.7 & $\begin{array}{l}\text { I find it easy to work in collaboration with } \\
\text { others }\end{array}$ & 5 & 4 & 3 & 2 & 1 \\
\hline 5.8 & I am successful in communicating verbally & 5 & 4 & 3 & 2 & 1 \\
\hline 5.9 & $\begin{array}{l}\text { I identify the need for inter-disciplinary links for } \\
\text { maintaining social harmony }\end{array}$ & 5 & 4 & 3 & 2 & 1 \\
\hline 5.10 & $\begin{array}{l}\text { I am able to express my ideas effectively in } \\
\text { writing }\end{array}$ & 5 & 4 & 3 & 2 & 1 \\
\hline 5.11 & I am able to express my views freely & 5 & 4 & 3 & 2 & 1 \\
\hline 5.12 & $\begin{array}{l}\text { I find it challenging to pursue learning in a } \\
\text { culturally diverse milieu }\end{array}$ & 5 & 4 & 3 & 2 & 1 \\
\hline 5.13 & 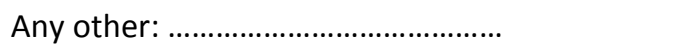 & 5 & 4 & 3 & 2 & 1 \\
\hline
\end{tabular}

Once you have responded to all the items of the SRSSDL transfer the scores to the correct boxes below and add up your scores as in the following example.

\begin{tabular}{|c|c|c|c|c|c|c|}
\hline Score & 5 & 4 & 3 & 2 & 1 & \\
\hline Items 1.1 - 1.12 & 3 & 4 & 3 & 5 & 0 & \\
\hline Total & 15 & 16 & 9 & 10 & 0 & Total Score $=50$ \\
\hline Score & 5 & 4 & 3 & 2 & 1 & \\
\hline \multicolumn{7}{|l|}{ Items 1.1 - 1.12} \\
\hline Total & & & & & & Total Score = \\
\hline
\end{tabular}




\begin{tabular}{|c|c|c|c|c|c|c|}
\hline Score & 5 & 4 & 3 & 2 & 1 & \\
\hline Items $2.1-2.12$ & & & & & & \\
\hline Total & & & & & & Total Score $=$ \\
\hline
\end{tabular}

\begin{tabular}{|c|c|c|c|c|c|c|}
\hline Score & 5 & 4 & 3 & 2 & 1 & \\
\hline Items $3.1-3.12$ & & & & & & \\
\hline Total & & & & & & Total Score $=$ \\
\hline
\end{tabular}

\begin{tabular}{|c|c|c|c|c|c|c|}
\hline Score & 5 & 4 & 3 & 2 & 1 & \\
\hline Items $4.1-4.12$ & & & & & & \\
\hline Total & & & & & & Total Score = \\
\hline
\end{tabular}

\begin{tabular}{|c|c|c|c|c|c|c|}
\hline Score & 5 & 4 & 3 & 2 & 1 & \\
\hline Items $5.1-5.12$ & & & & & & \\
\hline Total & & & & & & Total Score $=$ \\
\hline
\end{tabular}

Add all the total scores

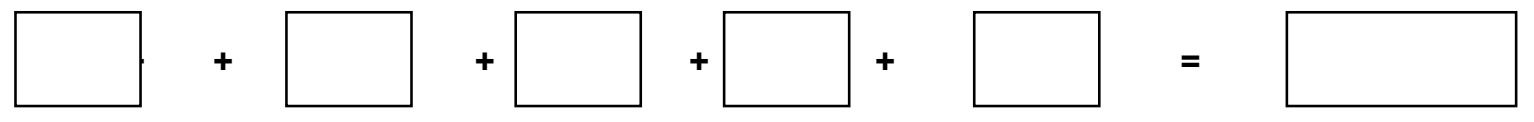

Check the total score with the following scoring range in order to identify your level of self-directedness in learning.

\begin{tabular}{|c|c|c|}
\hline Scoring range & $\begin{array}{c}\text { Level of Self- directedness in } \\
\text { learning }\end{array}$ & Interpretation \\
\hline $60-140$ & Low & $\begin{array}{c}\text { Guidance is definitely needed from the teacher. Any } \\
\text { specific changes necessary for improvement must be } \\
\text { identified and a possible complete re-structuring of the } \\
\text { methods of learning. }\end{array}$ \\
\hline $141-220$ & Moderate & $\begin{array}{c}\text { This is half way to becoming a self-directed learner. } \\
\text { Areas for improvement must be identified, evaluated } \\
\text { and a strategy adopted with teacher guidance when } \\
\text { necessary. }\end{array}$ \\
\hline $221-300$ & High & $\begin{array}{c}\text { This indicates effective self-directed learning. The goal } \\
\text { now is to maintain progress by identifying strengths and } \\
\text { methods for consolidation of the students' effective } \\
\text { self-directed learning. }\end{array}$ \\
\hline \multicolumn{2}{|c|}{}
\end{tabular}

No matter what your total score, it is essential that you pay particular attention to any individual items of the SRSSDL in which you have scored below 3 as these are the areas in which you may need to improve. 
Thank you for completing the questionnaire.

SRSSDL tool source:

Williamson SN (2007) The Development of Self-Rating Scale of Self-Directed Learning. Nurse Researcher $14(2): 65-72$. 